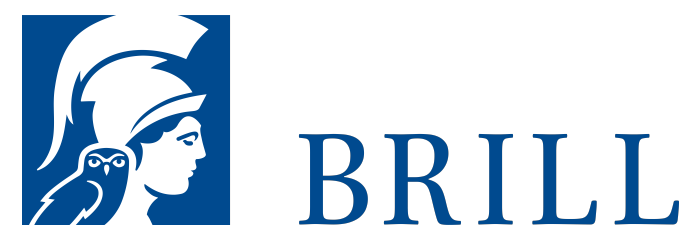

\title{
The Capitulations and the Ottoman Legal System
}

Qadis, Consuls and Beratlıs in the 18th Century

Author: Maurits van den Boogert

Pre-modern Western sources generally claim that European mercantile communities in the Ottoman Empire enjoyed legal autonomy, and were thus effectively immune to Ottoman justice. At the same time, they report numerous disputes with Ottoman officials over jurisdiction ("avanias"), which seems to contradict this claim, the discrepancy being considered proof of the capriciousness of the Ottoman legal system. Modern studies of Ottoman-European relations in this period have tended uncritically to accept this interpretation, which is challenged in this book.

\section{Readership}

All those interested in legal history, the history of Islamic law, the history of the Ottoman Empire, the history of EuropeanOttoman relations, as well as historians of the Middle East in general.

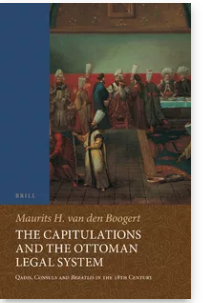

Pages: xvi, 328

pp.

Language:

English

Subjects:

Islamic Law,

Middle East and

Islamic Studies

Publisher: Brill

Series:

Studies in

Islamic Law and Society, Volume: 21

E-Book (PDF)

Released online:

23 Nov 2020

ISBN: 978-90-

47-40612-9

List price

USD $\$ 213.00$

Hardback

Publication date: 18 May 2005

ISBN: 978-90-

04-14035-6

List price

USD \$213.00

Paperback

Publication date: $2 \mathrm{OFeb} 2 \mathrm{O} 2 \mathrm{O}$ 
Maurits H. van den Boogert, Ph.D. (Leiden, 2001) is the 04-42862-1

List price (co-)editor of four volumes on Ottoman-European relations, including The Ottoman Capitulations: Text and Context (Rome, 2003, with Kate Fleet) and Friends and Rivals in the East (Brill, 200o, with Alastair Hamilton and Alexander de Groot). In 2010 he published Aleppo Observed: Ottoman Syria Through the Eyes of Two Scottish Doctors, Alexander and Patrick Russell (Oxford University Press). He is now the Publishing Director for Middle East, Islam, and African Studies at Brill.

For more information see brill.com

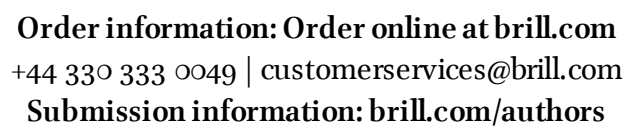

Titles published by Brill | Fink, Brill | mentis or Brill | Schöningh: +49(o)71 5413279216 | brill@brocom.de 